\title{
Monoclonal Antibodies Against LipL32, the Major Outer Membrane Protein of Pathogenic Leptospira: Production, Characterization, and Testing in Diagnostic Applications
}

\author{
CLÁUDIA P.H. FERNANDES, ${ }^{1,2}$ FABIANA K. SEIXAS, ${ }^{1}$ MARIANA L. COUTINHO, ${ }^{1}$ \\ FLÁVIA A. VASCONCELLOS, ${ }^{1}$ NÚBIA SEYFFERT, ${ }^{1}$ JULIO CRODA, ${ }^{3}$ ALAN J. MCBRIDE, ${ }^{3}$ \\ ALBERT I. KO, ${ }^{3,4}$ ODIR A. DELLAGOSTIN,${ }^{1}$ and JOSÉ A.G. ALEIXO ${ }^{1}$
}

\begin{abstract}
Pathogenic serovars of Leptospira have a wide antigenic diversity attributed mainly to the lipopolysacharide present in the outer membrane. In contrast, antigens conserved among pathogenic serovars are mainly represented by outer membrane proteins. Surface exposure of a major and highly conserved outer membrane lipoprotein (LipL32) was recently demonstrated on pathogenic Leptospira. LipL32 in its recombinant form (rLipL32) was used to immunize BALB/c mice to develop murine monoclonal antibodies (MAbs). Three MAbs against rLipL32 were produced, isotyped, and evaluated for further use in diagnostic tests of leptospirosis using different approaches. MAbs were conjugated to peroxidase and evaluated in a native protein enzymelinked immunosorbent assay (ELISA) with intact and heat-treated leptospiral cells, conjugated to fluorescein isothiocyanate (FITC) for indirect immunofluorescence with intact and methanol fixed cells and were used for LipL32 immunoprecipitation from leptospiral cells. rLipL32 MAbs conjugated to peroxidase or used as primary antibody bound to intact and heat-treated cells in ELISA, proving that they could be used in enzyme immunoassays for detection of the native protein. In immunofluorescence assay, MAbs labeled bacterial cells either intact or methanol fixed. Two MAbs were able to immunoprecipitate the native protein from live and motile leptospiral cells and, adsorbed onto magnetic beads, captured intact bacteria from artificially contaminated human sera for detection by polymerase chain reaction (PCR) amplification. Results of this study suggest that the MAbs produced can be useful for the development of diagnostic tests based on detection of LipL32 leptospiral antigen in biological fluids.
\end{abstract}

\section{INTRODUCTION}

$\mathbf{L}$ EPTOSPIROSIS, A ZOONOTIC DISEASE widespread in the world, is caused by pathogenic bacteria of the genus Leptospira. ${ }^{(1)}$ There are over 230 pathogenic leptospiral serovars identified and this antigenic diversity is mainly attributed to the lipopolysacharide (LPS) covering bacterial surface. ${ }^{(2)}$ Diagnostic approaches based on detection of antibodies generated during infection or on detection of antigens using antibodies generated against Leptospira strains have poor sensitivity because LPS is the dominant antigen and antibody reaction is serovar specific. Because of the LPS diversity, recent research focused on the use of outer membrane proteins (OMPs) conserved among pathogenic Leptospira species to increase sensitivity of diagnostic tests.

A small number of leptospiral outer membrane lipoproteins are exposed on the cell surface, among which are LipL32, LipL21, and LipL41. (3) Expression of the major OMP LipL32 has been demonstrated both in culture and in host infections, ${ }^{(4)}$ and its surface exposure on the bacterial membrane has recently been proven. ${ }^{(3)}$ Sera from patients with leptospirosis react strongly with the recombinant form of LipL32 ${ }^{(5)}$ and an enzyme assay using this antigen was able to detect human ${ }^{(6)}$ and animal cases of leptospirosis. ${ }^{(7,8)}$

\footnotetext{
${ }^{1}$ Centro de Biotecnologia and ${ }^{2}$ Faculdade de Medicina Veterinária, Universidade Federal de Pelotas, Pelotas, Brazil.

${ }^{3}$ Centro de Pesquisas Gonçalo Moniz, Fundação Oswaldo Cruz, Salvador, Brazil.

${ }^{4}$ Division of International Medicine and Infectious Disease, Weill Medical College, Cornell University, New York.
} 
In this study we report on the production and characterization of three monoclonal antibodies (MAbs) against recombinant LipL32 (rLipL32) and their use in different approaches to demonstrate their potential for diagnosis of leptospirosis. The MAbs recognized the native protein on the surface of pathogenic Leptospira cells and did not react with saprophytic strains or other microorganisms, suggesting they could be a useful diagnostic tool for leptospirosis.

\section{MATERIALS AND METHODS}

\section{Leptospira strains and culture conditions}

L. interrogans serovar Copenhageni strain FIOCRUZ L1 130 used in this study was provided by A.I. Ko (Centro de Pesquisa Gonçalo Moniz, FIOCRUZ, Salvador, BA, Brazil). Other Leptospira serovars used were obtained from the Center for Zoonosis Control (Universidade Federal de Pelotas, Brazil). Leptospires were grown at $30^{\circ} \mathrm{C}$ in Ellinghausen-McCullough-JohnsonHarris (EMJH) medium (Becton Dickinson Co., MD), supplemented with $8 \%$ of bovine serum albumin. ${ }^{(1)}$

\section{Antigen preparation}

The lipL32 gene, obtained by polymerase chain reaction (PCR) using the DNA from L. interrogans L1 130 as template, was cloned into the pAE expression vector ${ }^{(9)}$ that allows fusion of the protein with a $6 \times$ His tag. This plasmid was used to transform Escherichia coli BL21 (DE3). Purification of the protein was accomplished by affinity chromatography with Ni-NTA resin using the QIA EXPRESSIONIST Kit (Qiagen Corporation, Valencia, CA) following the manufacturer's instructions. The eluate was then dialyzed against phosphate-buffered saline (PBS) and glycine $0.1 \%, \mathrm{pH} 8.0$, for approximately 16 hours at $4^{\circ} \mathrm{C}$. Protein in the final preparation was quantified by the Bradford method. ${ }^{(10)}$

\section{Generation and purification of MAbs}

Two 6-week-old BALB/c female mice were immunized intraperitoneally on day 1 with $100 \mu \mathrm{g}$ of the recombinant protein LipL32 (rLipL32) mixed with Freund's complete adjuvant (Sigma Aldrich Co., St. Louis, MO). This was followed by three intraperitoneal injections of rLipL32 mixed with Freund's incomplete adjuvant (Sigma Aldrich) on days 14, 21, and 28. Three days before fusion the mouse with the highest titer of serum antibodies against rLipL32 in an indirect ELISA was boosted with $20 \mu \mathrm{g}$ of the protein intravenously. Hybridoma cells were obtained by established procedures. ${ }^{(11)}$ Splenic lymphocytes were fused to murine Sp2/O-Ag14 myeloma cells in the presence of PEG 1450 (Sigma Aldrich). Fused cells were cultivated in Dulbecco's modified Eagle's medium (DMEM; Sigma Aldrich) containing 20\% fetal calf serum (FCS; Cultilab, Campinas, Brazil) and supplemented with hypoxanthine, aminopterin, and thymidine (HAT; Sigma Aldrich). Hybridomas were primarily screened for specific antibodies by indirect ELISA with immunizing antigen. Supernatants showing at least $40 \%$ of the positive control (sera from rLipL32 immunized mouse) OD were considered positive and the hybridomas cloned twice by limiting dilution. A secondary screening was performed by immunoblotting and indirect ELISA using supernatant from cloned cells and heat-treated Leptospira from different serogroups as antigen. Specific hybrid cell lines identified in this second screening were expanded and stored in liquid nitrogen. For ascites production the hybridomas were removed from liquid nitrogen, cultivated on DMEM with $10 \%$ FCS, collected by centrifugation, washed five times in DMEM without FCS, and injected into pristane-primed BALB/c mice. MAbs were purified from ascitic fluid by affinity chromatography on a protein A-Sepharose CL-4B column (GE Healthcare Company, Piscataway, NJ) according to the manufacturer's instructions. Purification efficacy was evaluated by SDS-PAGE and final concentration was measured by spectrophotometry at $280 \mathrm{~nm}$. Purified MAbs were stored at $-20^{\circ} \mathrm{C}$. The MAbs were isotyped by ELISA with a mouse subisotyping kit following manufacturer instructions (Sigma Aldrich).

\section{Gel electrophoresis and immunoblotting}

Proteins immunoprecipitated from outer membrane or heattreated leptospiral cells were solubilized in final sample buffer $50 \mathrm{mM}$ Tris- $\mathrm{HCl}$ (pH 6.8), $100 \mathrm{mM}$ dithiothreitol, $0.1 \%$ bromophenol blue, $2 \%$ SDS, and $20 \%$ glycerol and separated in a $12 \%$ polyacrylamide gel using a discontinuous buffer system. ${ }^{(12)}$ After electrophoresis, the gels were stained with $0.2 \%$ Coomassie brilliant blue R-250 (in 10\% acetic acid- $45 \%$ methanol) or transferred electrophoretically to a polyvinylidene difluoride (PVDF) membrane (GE Healthcare) at 25 volts for 60 minutes. The membranes were blocked with $0.1 \mathrm{M}$ PBS containing $0.1 \%$ Tween 20 (PBS-T, pH 7.4) and 5\% skim milk for 30 minutes, washed twice in PBS-T and incubated for 1 hour with the MAbs diluted 1/1000 in PBS-T. After washing the membrane three times with PBS-T, a rabbit anti-mouse immunoglobulin ( $\mathrm{Ig}$ ) horseradish peroxidase conjugate (Sigma Aldrich) diluted 1:2000 in PBS-T or a MAb anti-LipL32 peroxidase conjugate was added for 1 hour and the membrane was again washed three times with PBS-T. The MAb-peroxidase conjugate was prepared according to established protocol. ${ }^{(13)}$ Bands were visualized after the addition of the substrate/chromogen solution $\left(\mathrm{H}_{2} \mathrm{O}_{2}\right.$ /4-chloro-1-naphtol).

\section{ELISA with intact and heat-treated leptospiral cells}

Seven-day cultures of L. interrogans serovar Copenhageni strain Fiocruz L1 130, and of saprophytic L. biflexa serovar patoc (strain Patoc I) were harvested by centrifugation $(15,000 \mathrm{~g}$, for 30 minutes) at $4^{\circ} \mathrm{C}$ and washed once in PBS $(0.01 \mathrm{M}, \mathrm{pH}$ 7.2). The cells were resuspended in PBS, counted in a PetroffHausser chamber and the concentration was adjusted to approximately $10^{9}$ cells per milliliter. For ELISA with intact leptospira cells, microtiter plates (Nunc Polysorp, Nalge Nunc International, Rochester, NY) were first coated overnight at $4^{\circ} \mathrm{C}$ with $100 \mu \mathrm{L}$ of a 10 times diluted $0.1 \%$ poly L-lysine solution and then with $100 \mu \mathrm{L}$ of the bacterial suspension in PBS for 2 hours at $30^{\circ} \mathrm{C}$. Wells were washed 3 times with leptospira culture medium (LCM) and $100 \mu \mathrm{L}$ of twofold dilutions of each ascites MAb in LCM was added to the wells for 2 hours at $30^{\circ} \mathrm{C}$. Washing was repeated and $100 \mu \mathrm{L}$ of rabbit anti-mouse Ig-POase conjugated was added for 2 hours at $30^{\circ} \mathrm{C}$. After 2 
washes with LCM and 3 washes with PBS, $100 \mu \mathrm{L}$ of enzyme substrate/chromogen solution $\left(\mathrm{H}_{2} \mathrm{O}_{2}\right.$ /ortophenylenediamine) in citrate-phosphate buffer, $\mathrm{pH}$ 5.0, was added and the reaction was allowed to take place in the dark for 10 minutes. Optical density was read at $450 \mathrm{~nm}$ in an ELISA reader (Multiskan MCC/340, Titertek Instruments, Huntsville, AL). ELISA with heat-treated leptospiral cells was performed in the same way except that leptospiral cultures were first inactivated overnight at $56^{\circ} \mathrm{C}$ and stored at $-20^{\circ} \mathrm{C}$ until use. As control of cell integrity, rat serum against cytoplasmatic protein GroEL was included in both tests. To investigate how protein conjugation would affect MAb performance in ELISA, a conjugate of MAb 1D9 and POase was also used in this experiment.

\section{Direct and indirect immunofluorescence}

Slide chambers (ICN Biomedicals Inc., Costa Mesa, CA) were coated with a $0.01 \%$ Poly L-lysine solution (Sigma Aldrich) and dried for 1 hour at room temperature. A 7-day culture of L. interrogans L1-130 was washed once in PBS, resuspended to a density of $10^{8}$ cells per milliliter in PBS, and incubated in the slide chamber for 2 hours at $30^{\circ} \mathrm{C}$. The slides were washed twice with LCM and coated with MAb ascites diluted 1:10 in LCM. After incubating for 1 hour at $30^{\circ} \mathrm{C}$, the slides were washed again twice with LCM and a 1:100 dilution of rabbit anti-mouse FITC conjugate was added and incubated for 1 hour in a dark humid chamber at $30^{\circ} \mathrm{C}$. After washing with LCM a drop of mounting medium was added and a coverslip was sealed with acrylic. In experiments with permeabilized membrane, slides were incubated in $5 \mathrm{~mL}$ of methanol for 10 minutes at $4{ }^{\circ} \mathrm{C}$ followed by washing twice with LCM. The following controls were used in this experiment: (1) MAb against Salmonella OMP was used as primary antibody, (2) rabbit antimouse FITC conjugate was applied to slides without primary antibody, and (3) normal mouse serum was used as primary antibody. For direct immunofluorescence MAb 1D9 FITC conjugate was produced following established procedures ${ }^{(14)}$ and used together with a conjugate of rabbit antibodies against whole Leptospira and FITC (Ames Laboratories, National Veterinary Services Laboratory, Ames, IA) as positive control. Labeling was visualized by fluorescence microscopy (Olympus BX 51) with excitation wavelength of $450 \mathrm{~nm}$.

\section{Immunoprecipitation of native LipL32 and immunomagnetic separation of leptospiral cells}

Surface immunoprecipitation of native LipL32 was performed according to Shang et al. ${ }^{(15)}$ with modifications. A 2$\mathrm{mL}$ volume of each heat-inactivated MAb ascites was mixed with $30 \mathrm{~mL}$ of a culture of L. interrogans L1-130 containing $3 \times 10^{10}$ actively motile bacteria. After shaking the suspension gently for 1 hour at $30^{\circ} \mathrm{C}$ the cells were pelleted at $2000 \mathrm{~g}$ for 15 minutes at $4^{\circ} \mathrm{C}$, resuspended in PBS with $5 \mathrm{mM} \mathrm{MgCl} 2$, centrifuged again, and resuspended in $9 \mathrm{~mL}$ of $10 \mathrm{mM}$ Tris- $\mathrm{HCl}$ (pH 8.8), 2 mM ethylenediaminetetraacetic acid (EDTA), $1 \mathrm{mM}$ phenylmethyl sulfonyl fluoride (PMSF). A volume of $1 \mathrm{~mL}$ of $10 \%$ protein grade Triton $\times 100$ (Sigma Aldrich) was added and the suspension was agitated for 30 minutes at $4{ }^{\circ} \mathrm{C}$. The insoluble material was removed by centrifugation at $16,000 \mathrm{~g}$ for 20 minutes and $1 \mathrm{~mL}$ of $2 \%$ deoxycholate, $50 \mu \mathrm{L}$ of $20 \%$ SDS and $500 \mu \mathrm{L}$ of Sepharose-SpA (Sigma Aldrich) were added to the supernatant. After agitating the mixture gently for $30 \mathrm{~min}-$ utes at $4^{\circ} \mathrm{C}$, the complex of Sepharose SpA-MAb-antigen was washed by centrifugation two times with $0.01 \%$ Triton $\times 100$ in $10 \mathrm{mM}$ Tris- $\mathrm{HCl}(\mathrm{pH} 8.8)$ and resuspended in final sample buffer. The complex was submitted to SDS-PAGE and immunoblotting using MAb 1D9-POase as probe. As negative controls two additional immunoprecipitation experiments were carried out in parallel: in the first one MAb against LipL32 was omitted and in the second one the culture of L. interrogans L1130 was replaced with L. biflexa serovar patoc. For the immunomagnetic separation (IMS) procedure, 1D9 MAb was absorbed onto protein A-coated microspheres (Bangs Laboratories Inc., Fishers, IN). Briefly, $100 \mu \mathrm{L}$ of particles with $1 \%$ solids was suspended with $900 \mu \mathrm{L}$ of $50 \mathrm{mM} \mathrm{pH} 8.2$ borate buffer (BB), washed twice with $\mathrm{BB}$, resuspended in $1 \mathrm{~mL}$ of $\mathrm{BB}$ containing $1.2 \mathrm{mg}$ of MAb and incubated with gentle agitation at $4^{\circ} \mathrm{C}$ for 16 hours. The MAb-coated particles were washed twice with $\mathrm{BB}$ and resuspended in stock buffer $(100 \mathrm{mM}$ borate $\mathrm{pH}$ 8.5, $0.1 \%$ bovine serum albumin [BSA], 0.05 Tween 20, 10 $\mathrm{mM}$ EDTA, $0.1 \% \mathrm{NaN}_{3}$ ). An immunomagnetic separator (Invitrogen Corporation, Carlsbad, CA) was used in washing steps. Standard IMS was performed with $5 \mu \mathrm{L}$ of MAb-coated particles per milliliter of different dilutions of a pool of sterile human sera artificially contaminated with pathogenic and saprophytic Leptospira species. The serum samples were gently agitated for 15 minutes at room temperature and then washed twice on a magnetic separator. The particles were then resuspended in $20 \mu \mathrm{L}$ of lysis buffer $\left(0.02 \mathrm{M} \mathrm{Na}_{2} \mathrm{HPO}_{4} ; 0.15 \mathrm{M}\right.$ $\mathrm{NaCl}$; pH 7.2), boiled for 10 minutes and stored at $-20^{\circ} \mathrm{C}$ until use in polymerase chain reaction (PCR) as described below.

\section{PCR conditions}

PCR primers lipL32 F: 5' CGC TTG TGG TGC TTT CGG TGG T $3^{\prime}$ and lipL32 R: 5' CTC ACC GAT TTC GCC TGT TGG G 3' were used, resulting in a 264 bp amplicon of the lipL32 coding region. Briefly, $2 \mu \mathrm{L}$ of DNA-IMS template was added to a tube with $1 \mathrm{U} \mathrm{Taq}$ DNA polimerase (Invitrogen) 150 ng of primers, $2.5 \mu \mathrm{L}$ of $10 \times$ reaction buffer containing $\mathrm{MgCl}_{2}$ and $0.2 \mathrm{mM}$ dNTP. For DNA template optimization, volumes of $10 \mu \mathrm{L}, 5 \mu \mathrm{L}, 3 \mu \mathrm{L}, 2 \mu \mathrm{L}$, and $1 \mu \mathrm{L}$ of DNA-IMS were tested in the same conditions. Amplification was carried out in a Perkin Elmer 2400 thermocycler (PE Biosystems, Foster City, CA) with 1 cycle at $94^{\circ} \mathrm{C}$ for 5 minutes, 35 cycles at $94^{\circ} \mathrm{C}$ for 1 minute, $55^{\circ} \mathrm{C}$ for 1 minute, $72^{\circ} \mathrm{C}$ for 1 minute, and an extension of 7 minutes at $72^{\circ} \mathrm{C}$ at the end of the final cycle. Aliquots were analyzed by electrophoresis in $2 \%$ agarose gel with ethidium bromide and visualized under UV transillumination.

\section{RESULTS}

\section{Generation of MAbs}

From a total of 54 hybridomas tested in the primary ELISA, 3 , named 1D9, 36C4, and 412H4, have shown a specific reaction in the secondary ELISA screening and were selected for further characterization and testing in diagnostic applications. 
Table 1. Reactions of Anti-LipL32 MAbs with Different Strains of Leptospira in Immunoblotting

\begin{tabular}{|c|c|c|c|c|c|}
\hline \multirow[b]{2}{*}{ Serogroup } & \multirow[b]{2}{*}{ Serovar } & \multirow[b]{2}{*}{ Genomoespecies } & \multicolumn{3}{|c|}{$M A b s$} \\
\hline & & & $1 D 9$ & $412 \mathrm{H}$ & $36 C$ \\
\hline Australis & Australis & L. Interrogans & + & + & + \\
\hline Australis & Bratislava & L. Interrogans & + & + & + \\
\hline Autumnalis & Autumnalis & L. Interrogans & + & + & + \\
\hline Autumnalis & Butembo & L. Kirshneri & + & + & + \\
\hline Autumnalis & Rachmat & L. Interrogans & + & + & + \\
\hline Bataviae & Bataviae & L. Interrogans & + & + & + \\
\hline Canícola & Canícola & L. Interrogans & + & + & + \\
\hline Hebdomadis & Hebdomadis & L. Interrogans & + & + & + \\
\hline Icterohaemorrhagiae & Copenhageni & L. Interrogans & + & + & + \\
\hline Icterohaemorrhagiae & Icterohaemorrhagiae & L. Interrogans & + & + & + \\
\hline Pomona & Pomona & L. Interrogans & + & + & + \\
\hline Pyrogenes & Pyrogenes & L. Interrogans & + & + & + \\
\hline Sejroe & Wolffi & L. Interrogans & + & + & + \\
\hline Sejroe & Hardjo & L. Interrogans & + & + & + \\
\hline Djasiman & Sentot & L. Interrogans & + & + & + \\
\hline Djasiman & Djasiman & L. Interrogans & + & + & + \\
\hline Ballum & Castellonis & L. Borgpetersneii & + & + & + \\
\hline Ballum & Ballum & L. Borgpetersneii & + & + & + \\
\hline Celledoni & Withcombi & L. Borgpetersneii & + & + & + \\
\hline Javanica & Javanica & L. Borgpetersneii & + & + & + \\
\hline Tarassovi & Tarassovi & L. Borgpetersneii & + & + & + \\
\hline Cynopteri & Cynopteri & L. Kirshneri & + & + & + \\
\hline Grippotyphosa & Grippotyphosa & L. Kirshneri & + & + & + \\
\hline Louisiana & Louisiana & L. Noguchii & + & + & + \\
\hline Panamá & Panama & L. Noguchii & + & + & + \\
\hline Shermani & Shermani & L. Santarosai & + & + & + \\
\hline Celledoni & Celledoni & L. Weilii & + & + & + \\
\hline Andamana & Andamana & L. Biflexa & - & - & - \\
\hline Semaranga & Patoc & L. Biflexa & - & - & - \\
\hline Semaranga & Semaranga & L. Meyeri & - & - & - \\
\hline
\end{tabular}

MAbs, monoclonal antibodies.

The immunoglobulin classes of MAbs 1D9, 36C4, and 412H4 were IgG2b, IgG2a, and IgG3, respectively. All MAbs reacted with a band of an estimated molecular mass of $32 \mathrm{kd}$ and neither reacted with $E$. coli as seen by immunoblotting (Table 1).

\section{ELISA with intact and heat-treated leptospira}

To evaluate MAb reactivity against native LipL32 protein ELISA protocols with intact and heat-treated leptospiral cells were used. A decrease in the absorbance of ELISA with intact cells occurred as the concentration of antibodies decreased, demonstrating the specificity of the reaction (Fig. 1A). In addition, antisera against the cytoplasmatic protein GroEL did not react in this ELISA. A conjugate of MAb 1D9-POase reacted with native LipL32 in both intact and heat-treated cell ELISA, but higher absorbance values were observed with heat-treated bacteria (Fig. 1B). In these ELISA experiments MAbs did not react with saprophytic bacteria and sera against GroEL reacted with heat-treated cells (data not shown).

\section{Direct and indirect immunofluorescence}

Reaction of MAbs with native LipL32 on the outer membrane of pathogenic Leptospira was investigated by indirect immunofluorescence and by an in-house prepared conjugate of
MAb 1D9 and FITC. Bacterial cells were applied to slides with and without methanol treatment to evaluate the effect of the fixing method on MAb reactivity. The three MAbs labeled leptospiral cells in both fixing methods as could be seen by the intense fluorescence (Fig. 2). Labeling of leptospiral cells with $\mathrm{MAb}$ anti-Salmonella or normal mouse serum was not observed (data not shown).

\section{Immunoprecipitation of native LipL32 and use of a $M A b$ on IMS-PCR}

The MAbs were used in immunoprecipitation assays to investigate their ability in binding the surface of live and motile leptospiral cells in suspension. Two MAbs were able to precipitate LipL32 from the suspension of live pathogenic bacteria (Fig. 3). In addition, MAb 1D9 was adsorbed onto protein A magnetic beads to explore its potential for use in diagnostic assays, which associates IMS with PCR amplification. With the use of IMS for capturing bacterial cells prior to DNA extraction and PCR amplification, it was possible to detect as low as 10 leptospires per milliliter of artificially contaminated human sera (Fig. 4). Sera contaminated with saprophytic Leptospira submitted to IMS and PCR did not show any amplification product (data not shown). 
A

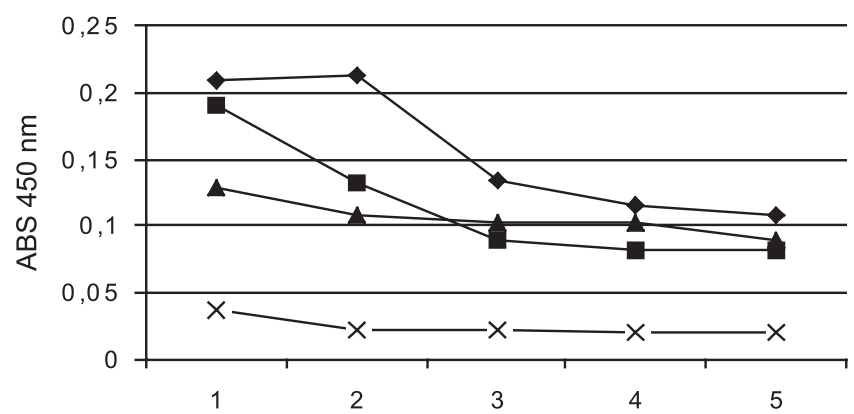

B

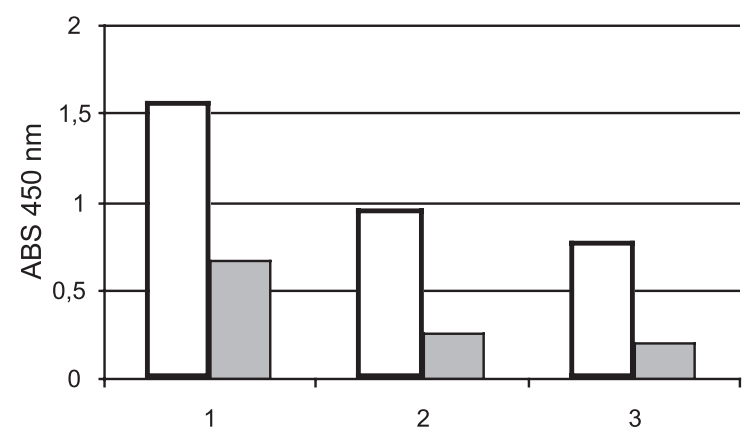

FIG. 1. Enzyme-linked immunosorbent assay (ELISA) reactions of monoclonal antibodies (MAbs) anti-LipL32 using intact and heat-treated L. interrogans L1-130 cells. A: ELISA using $10^{9}$ intact leptospiral cells per milliliter (100 $\mu$ l per well) and MAbs 1D9 $(\diamond), 412 \mathrm{H} 4(\boldsymbol{\square}), 36 \mathrm{C} 4(\mathbf{\Delta})$, and GroEL antiserum $(\times)$ diluted 1:4 (1), 1:8 (2), 1:16 (3), 1:32 (4), and 1:64 (5). B: ELISA reactions with intact $(\square)$ and heat-treated cells $(\square)$ at $10^{9}$ cell per milliliter (1), $4 \times 10^{8}$ cell per milliliter (2) and $2 \times 10^{8}$ cell per milliliter (3) and 1D9-POase conjugate diluted 1:1000.

\section{DISCUSSION}

Leptospiral outer membrane protein LipL32 is prominent on pathogenic strains and is the major detergent-phase protein extracted by Triton X 114. ${ }^{(4,16)}$ Human sera from cases of leptospirosis reacted with native LipL32 and its recombinant form expressed in E. coli. ${ }^{(5)}$ After these findings this antigen has been used for developing diagnostic tests that detect antibodies in human and animal leptospirosis. ${ }^{(6,7,17,18)}$ However, diagnostic tests based on antibody detection suffer from lack of sensitivity in the first 10 days of infection. Antigen detection tests should be preferred when early diagnosis is important for initiating treatment, as is the case of leptospirosis. ${ }^{(1,19)}$ MAbs are important tools for antigen detection tests because of their high specificity and permanent availability. The three MAbs reported in this study reacted with a $32-\mathrm{kd}$ polypeptidic band from dif-

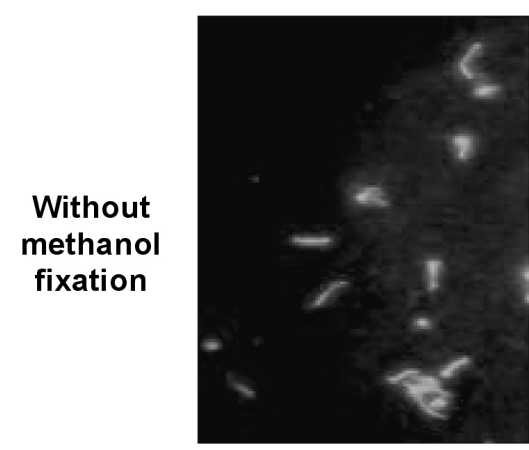

mAb $1 D 9$

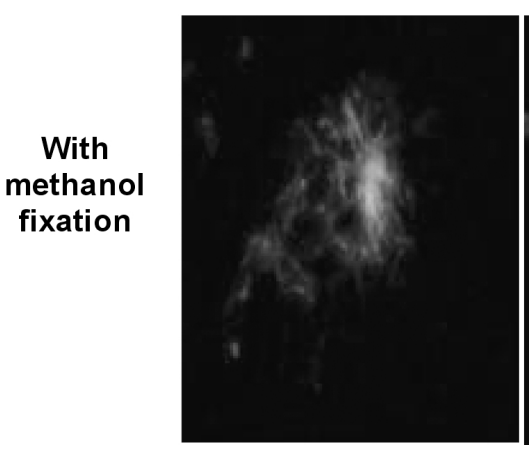

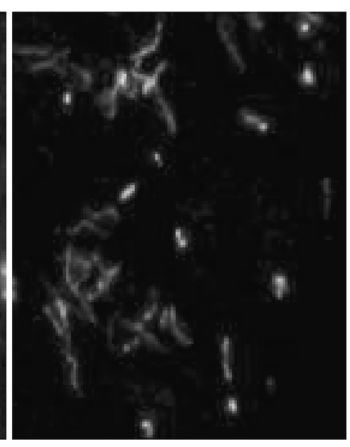

mAb 412 H4

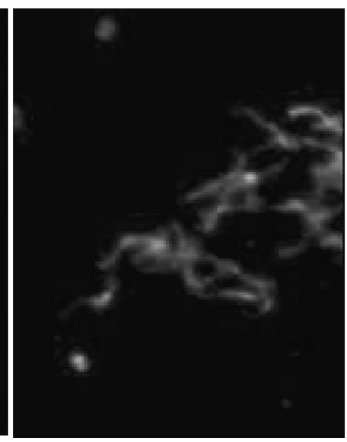

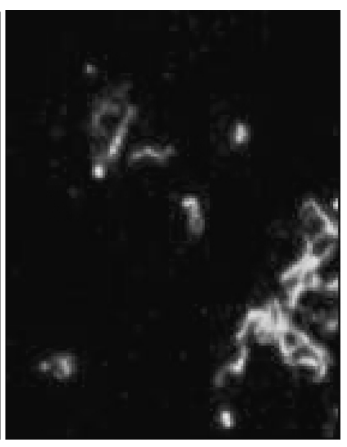

mAb 36C4

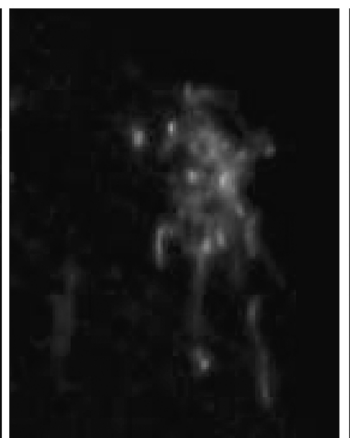

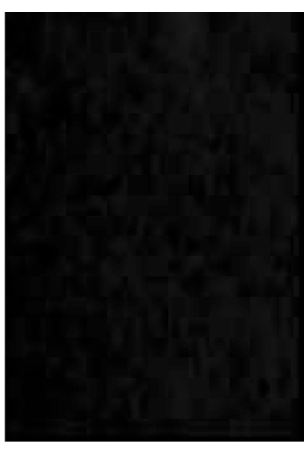

NMS

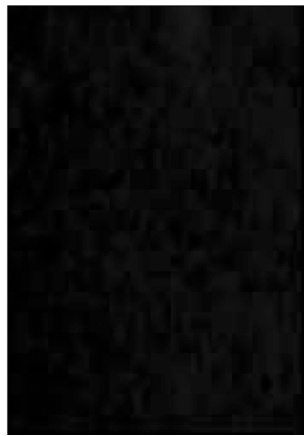

FIG. 2. Staining of LipL32 from L. interrogans L1-130 by indirect immunofluorescence. L. interrogans L1-130 was fixed to microscope slides with and without methanol and probed with monoclonal antibodies (MAbs). Test control slides were made by reacting fixed bacteria with normal mouse sera and rabbit anti-mouse fluorescein isothiocyanate (FITC). 


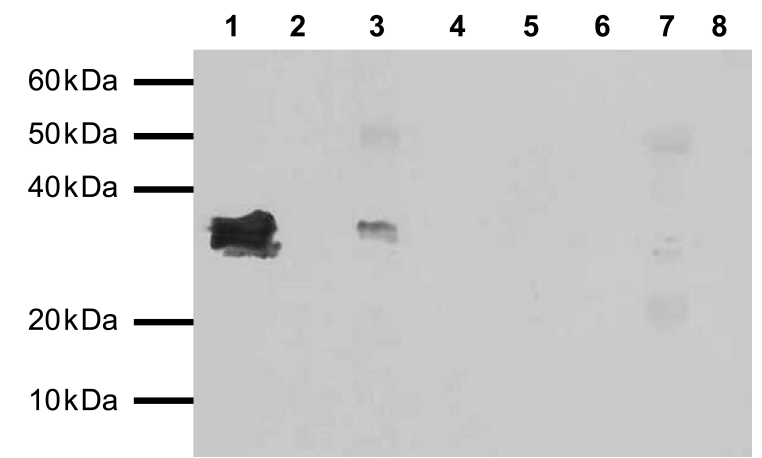

FIG. 3. Immunoprecipitation of native LipL 32 on the surface of L. interrogans L1-130. Bacterial cells were reacted with monoclonal antibodies (MAbs) before Triton X-100 membrane fractionation and precipitated with protein A-Sepharose. Precipitated material was separated by sodium dodecyl sulfatepolyacrylamide gel electrophoresis (SDS-PAGE) and blots were probed with MAb 1D9-POase. 1, rLipL32; 2, L biflexa Patoc, and MAb 1D9; 3, L. interrogans L1-130, and MAb 1D9; 4, L. biflexa Patoc and 412H; 5, L. interrogans L1-130 and 412H; 6, L. biflexa Patoc and 36C; 7, L. interrogans L1-130 and $36 \mathrm{C}$; and 8, L. interrogans L1-130 treated with protein A-Sepharose only.

ferent leptospiral serovars on immunoblotting, a molecular mass similar to that of LipL32. Moreover, anti-LipL32 MAbs 1D9, $36 \mathrm{C} 4$ and $412 \mathrm{H} 4$ did not react with the other microorganisms tested. The MAbs were also able to detect native LipL32 antigen when used as primary antibody in indirect ELISA with intact and heat-treated leptospiral cells. Furthermore, MAb 1D9 maintained antibody activity after conjugation with peroxidase suggesting it is suitable for two-site immunoassays such as sandwich ELISA.

Indirect immunofluorescence was used to investigate MAb reaction after fixing leptospiral cells with or without methanol treatment. When anti-LipL32 MAb 1D9 was used conjugated to FITC, it was possible to visualize leptospiral cells by direct fluorescence. MAbs have been successfully used in immunofluorescence based diagnostic tests for Lyme and syphilis, two diseases also caused by spirochetes. ${ }^{(20,21)}$ The antibodies reported here were able to attach to the bacterial outer membrane after the two fixing treatments, providing evidence of their usefulness for immunohistochemical tests.

Surface immunoprecipitation experiments were carried out to explore MAb potential for use in immunoseparation techniques or chromatographic assays. IMS has been used to increase PCR sensitivity and to improve bacterial isolation from clinical samples containing inhibitory substances or contaminating organisms. ${ }^{(22,24)}$ Two of the MAbs obtained in this study were able to form complexes with live leptospiral cells suspended in a liquid phase suggesting that they coud be useful for IMS. One of these MAbs was adsorbed to magnetic particles and used to develop a method for Leptospira detection in association with PCR amplification of the lipL32 gene. Using this novel method we were able to detect approximately 10 leptospiral cells per milliliter of human sera experimentally contaminated. An assay that uses MAb-based magnetic separation coupled to PCR amplification for detection of L. borgpetersenii serovar hardjo in urine from experimentally contaminated cattle has been reported. ${ }^{(25)}$ Despite its good sensitivity, the assay consistently detected 10 organisms in urine samples spiked with leptospires, it may have an important limitation in specificity since the mAbs used for IMS are directed to LPS or a noncharacterized outer envelope protein.

In conclusion, the results reported in this study demonstrated that MAbs generated against the recombinant form of LipL32 were able to recognize the native protein from pathogenic Leptospira. Because LipL32 is a surface protein conserved among pathogenic serovars and is not found on saprophytic strains, the MAbs against this target will be useful in the development of different test formats for diagnosis of human and animal leptospirosis.

\section{ACKNOWLEDGMENTS}

This work was supported by grants from Fundação Oswaldo Cruz (09224-7), Conselho Nacional de Desenvolvimento Científico e Tecnológico-CNPq (477609/2004-0) and National Institutes of Health, USA (AI034431 and TW00919). We are grateful to Dr. C.S. Brod from Center for Zoonosis ControlUFPel for Leptospira serovars and to Dr. D. Haake from UCLA, Los Angeles, CA, for providing the protocol for LipL32 purification and for fruitful discussions.
FIG. 4. Polymerase chain reaction (PCR) amplification of the lipL32 coding region from $L$. interrogans L1-130 after immunomagnetic separation from experimentally contaminated human sera. 1, DNA ladder; 2, L. biflexa Patoc $10^{7}$ cells per milliliter; $3,10^{7} ; 4,10^{6} ; 5,10^{5} ; 6,10^{4} ; 7,10^{3}$; $8,10^{2} ; 9,10^{1}$ cells per milliliter.

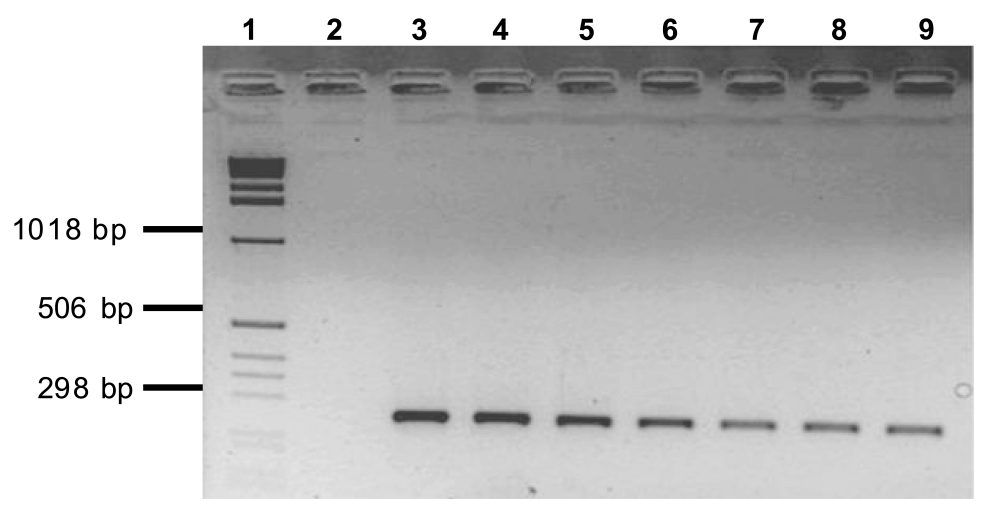




\section{REFERENCES}

1. Faine S, Adler B, Bolin CA, and Perolat P: Leptospira and Leptospirosis. MediSci, Melbourne, Austrália, 1999.

2. Bulach DM, Kalambaheti T, Pena-Moctezuma A, and Adler B: Lipopolysaccharide biosynthesis in Leptospira. J Mol Microbiol Biotechnol 2000;2:375-380.

3. Cullen PA, Xu X, Matsunaga J, Sanchez Y, Ko AI, Haake DA, and Adler B: Surfaceome of Leptospira spp. Infect Immun 2005;73: 4853-4863.

4. Haake DA, Chao G, Zuerner RL, Barnett JK, Barnett D, Mazel M, Matsunaga J, Levett PN, and Bolin CA: The leptospiral major outer membrane protein LipL32 is a lipoprotein expressed during mammalian infection. Infect Immun 2000;68:2276-2285.

5. Guerreiro H, Croda J, Flannery B, Mazel M, Matsunaga J, Galvao RM, Levett PN, Ko AI, and Haake DA: Leptospiral proteins recognized during the humoral immune response to leptospirosis in humans. Infect Immun 2001;69:4958-4968.

6. Flannery B, Costa D, Carvalho FP, Guerreiro H, Matsunaga J, Da Silva ED, Ferreira AG, Riley LW, Reis MG, Haake DA, and Ko AI: Evaluation of recombinant Leptospira antigen-based enzymelinked immunosorbent assays for the serodiagnosis of leptospirosis. J Clin Microbiol 2001;39:3303-3310.

7. Bomfim MR, Ko AI, and Koury MC: Evaluation of the recombinant LipL32 in enzyme-linked immunosorbent assay for the serodiagnosis of bovine leptospirosis. Vet Microbiol 2005;109:89-94.

8. Dey S, Mohan CM, Kumar TM, Ramadass P, Nainar AM, and Nachimuthu K: Recombinant LipL32 antigen-based single serum dilution ELISA for detection of canine leptospirosis. Vet Microbiol 2004;103:99-106.

9. Ramos CR, Abreu PA, Nascimento AL, and Ho PL: A high-copy $\mathrm{T} 7$ Escherichia coli expression vector for the production of recombinant proteins with a minimal N-terminal His-tagged fusion peptide. Braz J Med Biol Res 2004;37:1103-1109.

10. Bradford MM: A rapid and sensitive method for the quantitation of microgram quantities of protein utilizing the principle of protein-dye binding. Anal Biochem 1976;72:248-254.

11. Harlow E and Lane D: Antibodies: A Laboratory Manual. Cold Spring Harbor Laboratory Press, Cold Spring Harbor, NY, 1988.

12. Laemmli UK: Cleavage of structural proteins during the assembly of the head of bacteriophage T4. Nature 1970;227:680-685.

13. Tijssen P: Pratice and theory of enzyme immunoassays. In: Laboratory Techniques in Biochemistry, Vol. 15, Burton RH and Knippenberg PH (Eds). Elsevier Science Publishing Company, Inc., Amsterdam, 1985.

14. Windson BG: Conjugation of antibodies to fluorescein or rhodamine. In: Immunochemical Protocols, 3rd ed. Burns R (Ed.). Humana Press Inc, Totowa, NJ, 2005, pp. 131-134.
15. Shang ES, Summers TA, and Haake DA: Molecular cloning and sequence analysis of the gene encoding LipL41, a surface-exposed lipoprotein of pathogenic Leptospira species. Infect Immun 1996; 64:2322-2330.

16. Cullen PA, Cordwell SJ, Bulach DM, Haake DA, and Adler B: Global analysis of outer membrane proteins from Leptospira interrogans serovar Lai. Infect Immun 2002;70:2311-2318.

17. Tahiliani P, Kumar MM, Chandu D, Kumar A, Nagaraj C, and Nandi D: Gel purified LipL32: A prospective antigen for detection of leptospirosis. J Postgrad Med 2005;51:164-168.

18. Boonyod D, Poovorawan Y, Bhattarakosol P, and Chirathaworn C: LipL32, an outer membrane protein of Leptospira, as an antigen in a dipstick assay for diagnosis of leptospirosis. Asian Pac J Allergy Immunol 2005;23:133-141.

19. Levett PN: Leptospirosis. Clin Microbiol Rev 2001;14:296-326.

20. Chambers MA, Swango LJ, and Wright JC: Novel indirect fluorescent antibody test for Lyme disease. J Vet Diagn Invest 1996;8: 196-201.

21. Ito F, Hunter EF, George RW, Pope V, and Larsen SA: Specific immunofluorescent staining of pathogenic treponemes with a monoclonal antibody. J Clin Microbiol 1992;30:831-838.

22. Furdui VI and Harrison DJ: Immunomagnetic T cell capture from blood for PCR analysis using microfluidic systems. Lab Chip 2004; 4:614-618.

23. Stark M, Reizenstein E, Uhlen M, and Lundeberg J: Immunomagnetic separation and solid-phase detection of Bordetella pertussis. J Clin Microbiol 1996;34:778-784.

24. Olsvik O, Popovic T, Skjerve E, Cudjoe KS, Hornes E, Ugelstad $\mathrm{J}$, and Uhlen M: Magnetic separation techniques in diagnostic microbiology. Clin Microbiol Rev 1994;7:43-54.

25. Taylor MJ, Ellis WA, Montgomery JM, Yan KT, McDowell SW, and Mackie DP: Magnetic immuno capture PCR assay (MIPA): Detection of Leptospira borgpetersenii serovar hardjo. Vet Microbiol 1997;56:135-145.

Address reprint requests to: José Antonio Guimarães Aleixo, Ph.D. Centro de Biotecnologia Universidade Federal de Pelotas Caixa Postal 354 96010-900, Pelotas, RS Brazil

E-mail: biotjaga@ufpel.tche.br

Received for publication August 18, 2006. Accepted for publication October 26, 2006. 